\title{
Favorable Macro Environment: Formula of Investment Activity Growth under the Economic Paradigm Shifted
}

\author{
Ludmila Aleksandrovna Kormishkina \\ Evgeny Danilovich Kormishkin
}

Nadezhda Nickolaevna Semenova

Dmitry Alexandrovich Koloskov

\author{
Ogarev Mordovia State University, Saransk, Russian Federation
}

Email:nnsemenova@mail.ru

Doi:10.5901/mjss.2015.v6n4s4p163

\begin{abstract}
The article presents the results of study of the impact of the macro environment on investment activities in the Russian Federation for the period 1990-2014. The constructed economic and mathematical models, confirming quite substantial relationship between the dynamics of gross investments in fixed capital and the dynamics of gross profit as a potential source of financial investment in most of sectors of the Russian economy, indicate the need for a qualitative improvement of the macro environment in order to stimulate investment activity in the country during the passage to a new industrial development. The conclusion is that the neo-industrial investments (science-based, high-technology and innovative) act as a key condition for sustainable overcoming of the deindustrialization of production forces, as well as for the passing of the Russian economy to a new development paradigm. The article also makes recommendations regarding the creation of a favorable macro environment for investment activity of economic entities when shifting the paradigm of social and economic development. The recomendations envisage: optimization and reduction of the tax burden; maintenance of macro-economy ratio of profitability, interest rates and inflation; formation of a system of insurance against risk; state support of investments; reducition of corruption in the investment sphere.
\end{abstract}

Keywords: favorable macro environment, investment activity, gross fixed capital formation, neo-industrial development.

\section{Introduction}

\subsection{Introduction of the Problem}

The global financial and economic crisis of 2008-2009 proved once again, not only for Russia but also for other states, the vulnerability of the neoliberal model of the national economy, the implementation of which, according to the wellknown American economist and Nobel laureate P. Krugman (2008), was accompanied not only by a significant expansion of the financial sector but also by an enlargement of the gap between the real and virtual operation transactions and by a decline in reproduction trends.

The member of the Board of Directors of Soros Fund Managment, the creator of a worldwide charity fund network, the author of numerous works (including "The New Paradigm for Financial Markets", "The truth about the financial crisis") G. Soros $(2008,2012)$ sees the rational way out of the system and economic crisis in the strengthening of government regulation of the economy, which should create conditions for the growth of aggregate demand by means of massive investments.

Regarding the Russian economy, we note that it is experiencing depression, which, among other things, has purely internal cases. The financial and economic crisis of 2008-2009 showed once again the strong necessity of its orientation on raw material export. It seems that today there is no need to prove the obvious lag of the post-reform Russia's economy behind the level of industrialized countries. So, Russia has definitely no other way to overcome its technological backwardness and technological dependence, except for adopting a policy of high-tech industrialization which would be in line with modern challenges and historical situation changed. These days, most theorists and practitioners, including supporters of "liberal doctrine", are agreeing with this concept. 
It has to be said that if the early discussions regarding these issues were held on an academic level, but now, when the situation has aggravated, the problem of development of a new economic strategy, alternative to so-called liberal, has become more important for Russia than ever. In the last decade, a growing number of Russian scientists and economists (Grinberg, 2015; Gubanov 2012; Glaziev, 2010; Buzgalin, 2010; Ryazanov, 2013, 2014; Gazizullin, 2014; I.Y. Vaslavskaya and Y.Y. Yangirova, 2015) express a commitment to the idea of new industrialization.

The acknowledged founder of the neo-industrial paradigm of the modern stage of social and historical development in Russia became S.S. Gubanov (2012) who outlined his fundamental approach to the content, aims and objectives of neoindustrialization in his program work "Toward a policy for the neoindustrialization of Russia plus vertical integration". According to the scientific concept proposed by him, the present stage of social and economic development is marked by the entry into a new industrial age, historically higher, when top-qualified employees and knowledge workers compose a dominating part of the total labor force in society, and the science acts as a direct productive power (Gubanov, 2014). It gives rise to the development of scientific idea of "a new (post-industrial) economy" (Baily and Chakrabarti, 1988), which in its extended form covers the whole system of the macroeconomic consequences of new technology development accompagnied by changes in the structure of wealth and income of legal entities and individuals.

As a matter of fact, the concept of waves of innovation leads to a similar conclusion (Glaziev, 1990). A detailed study shows that the so-called VI and VII waves are neoindustrial and not postindustrial as they were interpreted earlier.

With regard to Russia, in the context of strategic plan, the neoindustrialization requires the adoption of a special economic policy oriented toward the internal driving force and internal dynamism of economic and social development that is not only able to overcome the de-industrialization of the country, but also able to restore Russia as a leading and independent industrial state in the world, technologically and economically independent from its geopolitical competitors (Riazanov, 2014, p.4).

The decisive condition for the implementation of a new economic paradigm is a goal-oriented investment activity based on the development of science and innovation cycles and the accumulation of highly intellectual human capital, on the replacement of labour-intensive production by a capital-intensive one, ensuring production of competitive products and technologies that forme the inflow of net cash income and revenues to the state budget. In these circumstances, the creation of a favorable macro environment in order to increase the investment activity of economic entities and to achieve rational (marginal) criteria of investment safety in relation to the modern Russian reality seems to be a priority goal.

\subsection{Importance of the Problem}

The efforts of the Russian Government to overcome the social-economic consequences of system and economic crisis of 2008-2009 and the huge cost of adoption of anti-crisis measures were not linked to the implementation of the priorities of long-term development of the country, to the creation of high-performance workplaces. The consequence of this policy was a stagnation of investment activity and growing difficulties in maintainance of volumes of current consumption and satisfaction of life needs of the Russian population.

As rightly noted by Professor V. Daskovskiy and V. Kiselev (2013, p.40), "without increasing investment in the restructuring of the economy based on neo-industrial technological structure, the current economy monetary pumping creates a 'postponed recession' trap via growing inflationary risks of self-destruction of the financial system". In this regard, the strategy of the Russian economy development should be based on the concept of new industrialization, which envolves a transfer to the automation of the productive forces, information, ecologization, formation of a new type of social reproduction, high-tech, science-based and eco-efficient. At the same time, one of the main conditions for the realization of this concept is the stability and safety of investment activity.

\subsection{Literature Review}

It is worth noting that there are diverse judgements in economic theory regarding the essence of the "investment" category. In particular, John Keynes (1936) defined investments as a part of the income that has not been used for consumption in the current period. In the study of the investment process, he underlined the relationship between investment and savings.

K. Makonnel and S. Brue (2008) consider investments as an element in the overall number of resources (land, capital, labor, business activity). According to them, "capital or investment funds are all the means of production used in the production of goods and in their delivery to the consumer".

American economists W. Sharp, G. Alexander, D. Bailey (1998) interprete the investment as an addition of current resources in the future cash flows. They try to explain the wide spreading of financial investments. In their "Investment" 
textbook, abovementioned scientists note that "in primitive economies the major portion of investments is real, while in the modern economy most of investments are financial. High development of the financial investment institute promotes the growth of real investments". E. Reinhold (2000, p.303) defines the investment as a "relationship based on the creation and distribution of money, information and material resources used in accordance with the target function of expansion of value".

On the basis of systematization and generalization of the best-known definitions of the "investment" category it can be concluded that the definition includes the entire set of conditions for reproduction, uncertainty, risk and wideness of choice. In this regard, we deem appropriate to consider investment as a hereditary category of reproduction and accumulation of capital, as a condition for the implementation of the expanded reproduction in the world that is getting more complicated in a qualitative sense, taking into account the increasing role of human importance.

In this context, at the moment we should talk about a qualitatively new - neo-industrial (high-technology, sciencebased and innovative) - type of investment, which corresponds to the essence and driving power of the new economic development paradigm. In our view, we should consider as such investments long-term investments in innovative sectors of the national economy, providing reindustrialization of the productive forces and the replacement of labour-intensive production by a capital-intensive one based on the creation and use of advanced equipment and technologies, overall development and efficient use of human and intellectual capital, etc.

In the process of economic paradigm shifting, scientists are paying special attention to the creation of macroeconomic and institutional conditions needed to promote sustainable investment activity in correspondence with the new objectives and priorities of economic development. It should be said that the theory of investment behavior was elaborated by many well-known economists. So, for example, John M. Keynes (1936) in his "General Theory of Employment, Interest and Money" rationalized the investment behavior model and formulated the "law of the marginal efficiency of capital". He established the relationship between the company investment behavior and internal macroeconomic policy of the state, proposed methods of state influence on the investment activity of firms. Among the main factors influencing the size of the investment, John M. Keynes emphasized the level of interest rates, budget and tax policy, the expected profitability of capital investments.

Significant contribution to the development of the theory of investment behavior was made by a famous American scientist D. Jorgenson $(1996,2001)$. In the analysis of the investment process in the US, D. Jorgenson has revealed the relationship between fiscal policy and the investment spending of companies. According to him, a key factor that impacts the level of capital investments of the company is the tax level in the country.

According to J. Kornai (1990), the amount of investment depends on expectations, risk level and confidence in the reasonability of investment. "Self-restraint and precautiousness of investors are probably one of the main reasons of general lack of sufficient demand to ensure full employment. It is therefore necessary to encourage potential investors to make investments"."

V.K. Senchagov (2010), member of the Russian Academy of Natural Sciences, professor of the Institute of Economics of the Russian Academy of Sciences, in his study of the Russian investment security specifies its fundamental macro-condition as follows: the profitability of the national economy must be greater than the level of lending rates and deposit rates and higher than the inflation rate.

\subsection{State Hypotheses and Their Correspondence to Research Design}

The favorable macro environment, providing creation of macroeconomic conditions (compliance with indicators of investment security and institutional environment) is the basis for the increase of investment activity during the passage to the new industrial development.

\section{Method}

\subsection{Historical and Genetic Approach}

The study of the influence of a favorable macro environment on investment activity in the national economy is based on the historical and genetic approach (Sorokin, 1992), the essence of which is to analyze historical trends of development, reproduction of historical and social logic of economic systems. When using this approach, the principle of systems acquires a different content. With this respect, in modern conditions the essence of the matter is not the system construction of a single universal theory regarding the problem in question, but rather the logically smooth statement of different (and interacting) theories and institutions, in their totality not only reflecting the essential aspects of the economic reality, but also allowing to understand them. 


\subsection{Regression Analysis}

During studies, the authors used a regression analysis, which allows identifying the main factors that determine the level and dynamics of the investment process. The main objective of regression analysis is to build an econometric model that allows obtaining the values of the dependent variable according the values of independent parameters. At the moment, the regression analysis is a main tool for studying relations between economic variables.

\subsection{Indicative Analysis}

As shown by numerous studies, the optimum method of detecting the degree of crisis in a particular field of socioeconomic development is the indicative analysis which is predetermined by the content of the general theory of economic security. In accordance with this, the diagnosis of state of the national economy should be based on the complex of criterial indices (indicators of economic security) that make it possible to estimate the potential danger, to make quantitative assessment of the degree of the crisis, to form a complex of program-targeted measures in order to stabilize the economic situation with regard to their location. The level of investment security risks is determined by comparing the actual (real) values of its performance indicators and their threshold (maximum allowable) values.

\section{Results}

In order to justify the need for a new industrialization of the economy of the modern Russia, the authors conducted in the article a macroeconomic analysis of factors of the dynamics and structure of investments in the economy during the 1990-2014. This analysis has showed that one of the distinguishing features of the functioning of the post-reform Russian economy in the 1990-ies was a reduction of investment (especially in the real sector), compared with the rate of decline in production. As a result, the structure of GDP was changed dramatically: in the amount of its end-use the share of gross fixed capital formation (a resumptive and comprehensive indicator of economic and investment security) fell from 38.7\% in 1990 to $20.3 \%$ in 2014, which corresponds to the level of 1960-1970-ies. At the same time, we know that when in the structure of the national economy the capital-intensive industries (first of all fuel-producing and raw materials industries) are dominating, these values of a specified indicator are clearly insufficient to overcome the economic stagnation and to implement the neoindustrialization (especially taking into account the strong depreciation of fixed assets). Meanwhile, the developed countries that had implemented modernization and the structure re-construction of the economy, maintained for a long period of time a high level of investment in fixed assets. For example, in post-war Europe before the 1970s the savings rate was not less than $25 \%$, in Japan - 30\%, in the period of Soviet industrialization the value was 33-35\% (Blagikh, 2014). The current level of gross fixed capital in Russia is lower than in Belgium, Latvia and France (Figure 1).

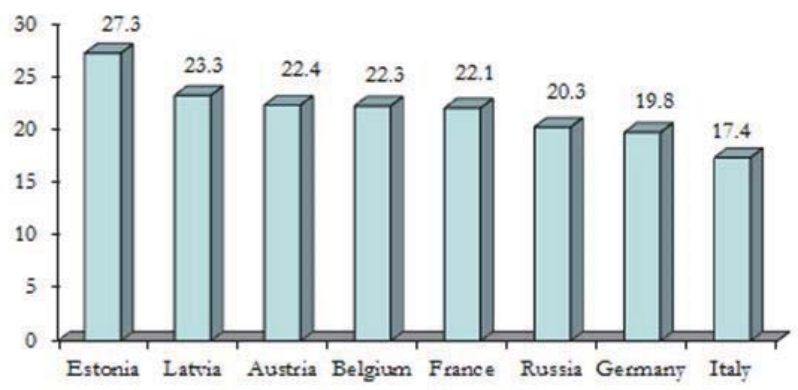

Figure 1. Gross fixed capital formation in various countries of the world, \%

It is worth noting that presently the average life of the active part of fixed assets in the Russian Federation is estimated at 20.3 years, which is more than 2 times higher than the standard term adopted in most developed countries. There is a growing level of depreciation of fixed assets, which in 2014 reached $49 \%$. The percent of obsolete equipment remains high (for reference: the percentage of industrial equipment in the age class under 5 years in the total amount of the equipment is currently $14 \%$ against $29.4 \%$ in 1990). Restraining influence on the development of the investment complex 
is also produced by a low level of capital consumption (0.7\% in 2014 against $1.9 \%$ in 1995) as well as by a general narrowing of the complex due to the destruction of its certain sectors and industries.

This means that the implementation of the re-industrialization of the Russian economy through the development of sience-based and high-tech (including nanotechnology) industries and entreprises becomes difficult without increasing their capital intensity. In connection with this, the share of the accumulation of GDP spent on investment in fixed assets, according to experts (Senchagov, 2010), should be increased from $20.3 \%$ existing in the present to $28-30 \%$ by sending them through the Russian Development Bank, in the first place, on innovation, targeted investment and venture business lending.

As for the structure of financing investments in the Russian economy regarding the source of funds, it has also undergone fundamental changes in the post-reform period. If before the start of the 1990s the main source of financing of the investment process in the Russian Federation was the budget, then during the 1990s the percent of equity funds of enterprises and organizations as a source of investment financing sharply increased (according to official statistics, in that period the value reached $63 \%$ of total investments). Although due to the rapid development of the banking sector and other financial institutions the share of equity funds in the financing of investment in the 2000 s decreased, at the present time its value remains significant: $48 \%$ (Fig. 2).

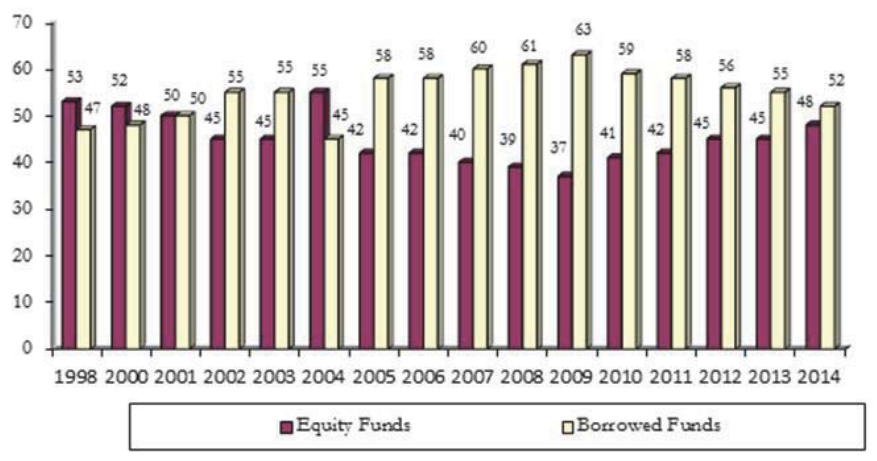

Figure 2. Structure of investments in fixed assets in Russia basen on financing sources, \%

In addition, the analysis of the dynamics of the ratio of own and borrowed funds in the amount of investment in fixed assets in the period 2009-2014 brings us to the conclusion about a growing trend concerning the share of equity funds and, on the contrary, a decrease trend regarding borrowed funds. In the structure of borrowed funds the budget funds $(16.2 \%)$ and bank loans (9.3\%) are dominated. This trend is essential for investment risk reducing.

Note that during the reform years the mode of use of own funds of enterprises and organizations has also undergone drastic changes: the scope of investment activity now covers not only the financing of fixed and working capital, but also long-term and short-term investments in securities, loans to other legal entities, the acquisition of land, objects of nature, patents, licenses and other operations. For this reason, the role of gross profit as a source of financing of capital investments could not change.

There is no doubt that the question of the degree of dependance of investments from current results of business activities is fundamentally important in the current social-economic situation. In this regard, the authors carried out the measurement of tightness of the relationship of investment in fixed capital and gross profit in two different ways.

1. The authors calculated the regression model which represents the relationship between the sectoral distribution of investments and sectoral distribution of gross profit in the Russian economy in 2013. The result was obtained by the following equation:

$\mathrm{I}=231.8876+0.0002 \mathrm{P}+\varepsilon . \mathrm{P}=6.425$

$1.125 \quad 2.534$

This equation is statistically significant by the Fisher test when the significance level of $a=0.03$, which confirms a moderate dependence of investments in fixed capital $(Y)$ from the gross margin $(X)(R=0.54)$. And the regression coefficient $a_{1}=0.0002$ is correct when the significance level of $a=0.03$.

The second way of calculation was based on the investments in fixed assets from the profit based on the residual values of $d l$ (gross domestic investment) and $d P$ (gross profit) after excluding the trend (trend component) established in 


\section{0-2013. (Table 1).}

Table 1. Regression models of the dependence of investment volumes in fixed assets on the profit after exclusion of the trend (trend component)

\begin{tabular}{|c|c|c|c|c|}
\hline No. & Industry sector & $\begin{array}{l}\text { Regression equation based on } d P \\
\text { and } d l \text { residues }\end{array}$ & $\begin{array}{l}\text { Determination } \\
\text { coefficient } \mathrm{R}^{2} \\
\end{array}$ & $\begin{array}{c}\text { F-test } \\
\mathrm{P} \\
\end{array}$ \\
\hline 1 & Agriculture, hunting and forestry & $\begin{array}{c}d l=0.00000+0.0015 d P \\
(0.00) \quad(2.41)\end{array}$ & 0.42 & 5.83 \\
\hline 2 & Fishing, fish farming & $\begin{array}{c}d l=0.0000+0.00026 d X \\
(0.00)(1.19)\end{array}$ & 0.15 & 1.42 \\
\hline 3 & Mineral production & $\begin{array}{c}d l=0.00000+0.000001 d P \\
(0.00) \quad(0.09)\end{array}$ & 0.01 & 0.01 \\
\hline 4 & Manufacturing & $\begin{array}{c}d l=0.00000+0.0003 d P \\
(0.00) \quad(0,68)\end{array}$ & 0.06 & 0.47 \\
\hline 5 & Manufacture of food products, beverages and tobacco & $\begin{array}{c}d l=0.00000+0.00004 d P \\
(0.00)(0.09)\end{array}$ & 0.001 & 0.01 \\
\hline 6 & Textile and clothing manufacture & $d Y=0.0000+0.00056 d X$ & 0.54 & 9.25 \\
\hline 7 & Manufacture of leather, leather products and footwear & $d Y=0.00000+0.00016 d X$ & 0.05 & 0.38 \\
\hline 8 & Processing of wood and manufacture of wood products & $\begin{array}{c}d Y=0.00000+0.00016 d X \\
(0.00)\end{array}$ & 0.41 & 5.49 \\
\hline 9 & Pulp and paper production; publishing and printing & $\begin{array}{c}d Y=0.00000+0.00065 d X \\
(0.00) \quad(3.04)\end{array}$ & 0.54 & 9.25 \\
\hline 10 & Manufacture of coke and refined petroleum products & $\begin{array}{c}d Y=0.00000+0.00009 d X \\
(0.00) \quad(3.96)\end{array}$ & 0.66 & 15.72 \\
\hline 11 & Chemical production & $\begin{array}{c}d Y=0.00000+0.00018 d X \\
(0.00) \quad(2.02)\end{array}$ & 0.34 & 4.08 \\
\hline 12 & Manufacture of rubber and plastic products & $d Y=0.00000+0.0001 d X$ & 0.05 & 0.38 \\
\hline 13 & Manufacture of other non-metallic mineral products & $d Y=0.00000+0.00026 d X$ & 0.41 & 5.49 \\
\hline 14 & Manufacture of basic metals and fabricated metal products & $d Y=0.00000+0.00015 d X$ & 0.33 & 3.88 \\
\hline 15 & Manufacture of machinery and equipment & $\begin{aligned} d Y= & 0.00000+0.00071 d X \\
& (0.00) \quad(3.69)\end{aligned}$ & 0.63 & 13.61 \\
\hline 16 & Manufacture of electrical and optical equipment & $\begin{array}{c}d Y=0.00000+0.00032 d X \\
(0.00) \quad(3.21)\end{array}$ & 0.56 & 10.28 \\
\hline 17 & Manufacture of transport and transport equipment & $d Y=0.00000+0.0001 d X$ & 0.18 & 1.75 \\
\hline 18 & Production and distribution of electricity, gas and water & $\begin{array}{c}d Y=0.00000+0.00002 d X \\
(0.00) \quad(0.12)\end{array}$ & 0.00 & 0.02 \\
\hline 19 & Construction & $\begin{array}{c}d Y=0.00000-0.00008 d X \\
(0.00) \quad(-0.93)\end{array}$ & 0.10 & 0.86 \\
\hline 20 & Transport and communications & $\begin{array}{c}d Y=0.00000+0.00126 d X \\
(0.00) \quad(1.47)\end{array}$ & 0.21 & 2.15 \\
\hline
\end{tabular}

Analysis of the data of the table 1 brings us to the conclusion about a strong influence of profit on the size of investment in fixed assets in the sectors of Russian economy, such as agriculture, textile and clothing manufacture, wood processing and manufacture of wood products, pulp and paper production; publishing and printing, chemical production, manufacture of other non-metallic mineral products, machinery and equipment, manufacture of coke and refined petroleum products, manufacture of electrical and optical equipment.

In general, the results of the analysis give grounds to assert that in the Russian economy of 1990-2013, the connection between the dynamics of investment in fixed assets and the dynamics of the gross profit as a potential source of financial investment is significant enough and is manifested as a general trend. In the context of a low rate of gross capital formation and dependance of investments in fixed assets from current results of business activities, from the 
standpoint of implementation of neoindustrialization tasks, there is a growing need to create a favorable macro environment in order to increase investment activity. This environment we define as a set of economic and institutional conditions (favorable or unfavorable) for the expanded capital formation and reproduction on the basis of innovation, that are based mostly on the observance of (or deviation from) threshold values of investment and economic security. Note that the absence of a favorable macro environment not only reduces the quality of the investment activity, but also promotes the growth of criminal activity in the investment sphere. The latter, under certain conditions, can turn into a system-forming process establishing conditions for its reproduction. Practice has shown that the criminalization in the investment sphere is capable intertwined with the regulatory and governing bodies and, therefore, has the long-term consequences for the development of economy and society.

\section{Discussion}

With regard to contemporary Russian realities, according to the authors, a key role in creating a favorable macro environment should be given to the following conditions:

(1) optimization and reduction of the tax burden on manufacturers. For Russian companies producing tangible goods and products, the actual tax burden is $40 \%$, which is certainly holding back the investment activity and economic growth of the country (Cashin, 2014). At the same time in the United States, Canada, Switzerland, Japan, the tax burden is $25-30 \%$. In Russia, the rate of corporate income tax is $20 \%$, which is $5 \%$ lower than in Latvia and Lithuania. And in foreign countries, the income tax rate is differentiated and depends on the income of the corporation. For example, in the United States the VAT is not provided for business (in the Russian Federation, its value is 18\%) and there is no property tax (in Russia - 2.2\%); purchased equipment that costs less than $\$ 2$ million per year are assessed when decommissioned based on its price cost; social security contributions amount to $13.3 \%$ (in Russia - 30\%).

From the perspective of the creation of a favorable macro environment as a factor encouraging investment activity in the real sector of the Russian economy, certain doubts have been raised by the proposition of the Government of the Russian Federation regarding the implementation of "tax maneuver", related to the shift in the 2015-2017 of source of budget revenues from the export and material sector by replacement of export duties with the increase of MET (Note 2). Such measures are in fact equivalent to an increase in the tax burden in this sector of the economy, which, undoubtedly, will lead to an inevitable increase in costs in the production of finished products and become an obstacle to the growth of investment activity.

With regard to the overall tax policy, it must itself be more selective and differentiated aiming at creation of additional incentives and preferences in promising areas of science-based and high-tech industries. In this regard, it is advisable to provide such enterprises with 'tax holidays' for a sufficiently long period and return the remission of taxes regarding all reinvested profits in high-tech areas of manufacturing sector.

(2) maintenance of the macro-financial ratio of profitability, interest rates and inflation. In the past decade, the average profitability of the real economy in Russia does not exceed $10 \%$ and at the beginning of 2015 it has been $8.6 \%$ (except for crude oil and natural gas production - 20.7\%; extraction of minerals, except for fuel and energy - $22.2 \%$, chemical industry - 22.4\%). The average interest rates on medium-term loans and long-term loans in the country, according to the Central Bank of Russia make $17.8 \%$, with deposits rates being $12.5 \%$.

In this regard, as a dissuasive factor we consider the raising of the key rate of the Central Bank of the Russian Federation from 5.5\% in September 2013 to 17\% in December 2014 and even its value decreased in June 2015 up to $11.5 \%$. Of course, such a policy of the Central Bank of the Russian Federation can be justified to a certain extent from the standpoint of monetary restraint of a surge in inflation and a certain counterstand to the capital outflow. However, it is clear that it causes serious damage to the interests of the credit support of the process of investment of the real production in the country.

After a careful analysis, the above relationship between the profitability of the real sector of the Russian economy explains many of problems existing at the moment related to the underinvestment and drift of the capital to speculative operations, as well as to its "illegal" outflow abroad. So, the higher the efficiency of investment projects and the lower interest rates are, the higher investment activity and entrepreneurial activity are. The more expensive credit resources are, the less efficient economy business projects and the lower investor demand are. High loan rates obstruct the movement of credit resources to the real sector and promote its technological degradation.

It is necessary to modernize the Russian money and credit domain, involving the effective use of all financial instruments. For example, it is possible not just provide loans to the banking organization by authorized 
mechanism of repo transactions, but also to create a domestic analogue of the monetary easing policy through direct purchase of financial assets - state corporate securities of Russian issuers. This mechanism is the postcrisis period has been introduced in the United States and some other industrialized countries and demonstrated a sufficiently high effectiveness. It is particularly important that any form of refinancing by the Central Bank of the Russian Federation was strictly earmarked in order to provide the real entry of monetary resources into the real sector of economy and to increase on this basis the gross fixed capital formation, so as to exclude the possibility of use of these resources in all kinds of speculation and currency transactions in the financial sector in the form of withdrawal of capital.

(3) creation of a system of investment risk insurance. These are the risks that inevitably arise in the field of investment of economic activity during the capitalization of financial assets and borrowed resources due to the necessity of reproduction and accumulation of fixed capital. They are reflected in the high bank credit rates and in a percentage of risk insurance used in the risk business sectors, etc. It seems reasonable to define criteria and indicators of investment security with regard to the different economic levels (macro, meso and micro level), taking into account the factors of investment risks (system-wide, sectoral, regional and microeconomical) and optimization of revenue of business entities according to risks and investment flows.

As a rule, most large investment projects are subject to the impact of the integrated risk universe, impeding the project execution. We consider that this situation can be solved by attraction for participation in such projects of specialized insurance companies that are able to reduce the impact of the investment risks.

(4) state support of investment activity. Objectives of neo-industrial modernization involving the enlargement of gross fixed capital formation in GDP, cannot be solved only at the expense of own and borrowed funds of economic entities. With this regard, the budget investment is an important factor of corporate capital attraction, so it enhances the investment activity. Usually for 1 ruble of budget allocations the business invests 3-5 rubles from its capital. The analysis of the structure of investments in fixed capital by sources of financing in the Russian Federation in 1998-2014 years has showed that in the domestic economy the average proportion of budget funds vs own funds is $1: 3$ rubles. In this situation, a promising form of participation of the state in solving the fundamental problems of neo-industrial modernization of the national economy should be a resultoriented budgeting.

(5) reduction of the level of corruption in the investment sphere. This problem needs to be solved by using a complex and legal approach that involves the improvement of legislation regarding the provision of favorable conditions for investment activities. Implementation of this approach involves: (a) a clear distinction between criminal elements and shady economic executives and fixation of this division in the new legal acts, including organised crime and anti-corruption legislation in the Criminal Code of the Russian Federation; (b) together with the income and expenditure declarations in the area of personal consumption it is advisable to use the socalled profit indulgences - legal documents certifying the legalization (upon payment of a special tax) of funds allocated for investment and economic activity; (c) the development and implementation of the program of repatriation of Russian capitals and their convertation into real investment resources of the Russian Federation. For Russian businessmen having withdrawn their capital abroad, the domestic market has significant advantages: knowledge of the conditions and business environment, connections with the regulatory and administrative bodies; (d) development and implementation of effective measures in order to protect the population of the state from financial frauds, provide guarantees and secure savings.

\section{Conclusion}

At the present time, the macroeconomic and institutional environment in Russia aside from not making a positive contribution to improving the investment activity of economic entities, also have a restraining effect on it and often leads to critical situations in the national economy. In this regard, the implementation of the above propositions predetermines the possibility to move to a new paradigm of economic and social development of the Russian economy.

\section{Acknowledgement}

This article has been prepared with financial support from the RGNF, project No.15-02-00174 a "Development of the theory and methodology of formation of innovative investments based on the paradigm of neo-industrial modernization". 


\section{References}

Amosov, A. (2015). Mozhno li otlozhit do 2017 g. povorot k novomu industrialnomu razvitiyu [ls it Possible to Postpone until 2017 the Turn to the New Industrial Development] Ekonomist - Economist, 3 (pp. 3-13) [in Russian].

Baily, M.N. and Chakrabarti A.K. (1988). Innovation and the Productivity Crisis. The Brookings Institution. - Washington. D.C.

Blagikh, I. (2014). Strana nuzjdaetsya v novoi industrializatsii [The Country Needs a New Industrialization] Ekonomist - Economist 10 (pp. 10-17) [in Russian].

Buzgalin, A.V. (2010). Rossiya - inaia strategiya [Russia: a Different Strategy] Filisofskie nauki, 9 (pp. 9-24) [in Russian].

Daskovskii, V., Kiselyov, V. (2013). O neoindustrialnoi modeli i strategii razvitiya ekonomiki [On the Neo-Industrial Models and Strategies of Economic Development] Ekonomist - Economist, 6, (pp. 34-49) [in Russian].

Fischer, S., Dornbusch, R., Schmalensee, S. (1995). Ekonomika [The Economy] Translated from the 2nd English edition - Moscow: Delo LTD, 1995 [in Russian].

Gazizullin, N.F. (2014). Novaya industrializatsiya Rossii. Teoreticheskie i upravlencheskie aspekty. Monografiya. [New industrialization of Russia. Theoretical and administrative aspects. Monograph] - St. Petersburg: NPK "Rost" [in Russian].

Glaziev, S.Y. (1990). Ekonomicheskaya teoriya tekhnicheskogo razvitiya [The Economic Theory of Technological Development]Moscow: Nauka [in Russian].

Glaziev, S.Y. (2010). Kakaya modernizatsiya nuzhna Rossii? [What Modernization does Russia Need?] Ekonomist - Economist, 8 (pp. 317) [in Russian].

Grinberg, R.S. (2015). Iz krizisa ne vyiti bez smeny ekonomicheskoi politiki [There is no Way Out of Crisis without Changement of Economic Policy] Vestnik instituta ekonomiki RAN - Bulletin of the Institute of Economics, Russian Academy of Sciences, 31 (pp. 7-9) [in Russian].

Gubanov, S. (2014). Neoindustrializatsiya Rossii i nishcheta ee sabotazhnoi kritiki [The Neoindustrialization of Russia and Poverty of its Sabotage Criticism] Ekonomist - Economist, 4 (pp. 3-31).

Gubanov, S.S. (2012). Derzhavnyi proryv. Neoindustrializatsiya Rossii $i$ vertikalnaya integratsiya [Toward a Policy for the Neoindustrialization of Russia Plus Vertical Integration] - Moscow: Knizhnyi mir [in Russian].

Jorgenson, D. (1996). Tax Policy \& the Cost of Capital, Cambridge, Mass, London: MIT Press

Jorgenson, D., Dale W., \& Kun-Young Yun (2001). Lifting the burden: Tax reform, the Cost of capital and U.S economic growthTax reform and U.S. economic growth. V. 3, Cambridge, Mass, London: MIT Press.

Kachin, V. (2014). V kakikh stranakh dolya nologov v VVP nizhe, chem v Rossii? [In Which Countries is the Share of Taxes in GDP Lower than in Russia?] - Argumenty i fakty, Retrieved from http://www.aif.ru/infographic/1178165 [in Russian]

Keynes, J.M. (1936). The General Theory of Employment, Interest, and Money. http://cas.umkc.edu/economics/people/facultypages/ kregel/courses/econ645/winter2011/generaltheory.pdf

Kornai, J. (1990) Defitsit [Deficit] - Moscow: Nauka, 1990 [in Russian].

Krugman, P. (2008). The Return of Depression Economics and the Crisis of 2008. W. W. Norton.

McConnell , C., Brue, S., Flynn, S. (2008). Economics. McGraw-Hill/Irwin.

Reinhold, E.A. (2000). Kategoriya "investitsii" v protsesse smeny ekonomicheskoi paradigmy v kn. pod red. Osipov Y.M., Zotova E.S. Ekonomicheskaya teoriya na poroge XXI veka-3 [The category of "investment" in the process of the economic paradigm shifting I In Osipov, Y.M. \& Zotova, E.S. (Eds) Economic theory on the threshold of XXI century -3 ] (pp. 294-306). - Moscow: Yurist [in Russian].

Ryazanov, V. (2013). Vremya dlya novoi industrializatsii: perspektivy Rossii [Time for a New Industrialization: Prospects of Russia.] Economist, 8, (pp. 3-32) [in Russian].

Ryazanov, V. (2014). Importozamashchenie i novaya industrializatsiya Rossii, ili kak preodolet stagnatsiyu [Import Substitution and New Industrialization of Russia, or How to Overcome Stagnation] Ekonomist - Economist, 11, (pp. 3-19) [in Russian].

Senchagov, V.K. (2010). Ekonomicheskaya bezopasnost Rossii. Obshchii kurs: uchebnik 3 izd. [The Economic Security of Russia. General course: textbook, 3rd edition] - Moscow: BINOM. Laboratoriya znaniy [in Russian].

Sharpe, W., Alexander, G., Bailey, J. (1998). Investments. Prentice Hall.

Sorokin, P.A. (1992). Chelovek. Tsivilizatsiya. Obschestvo [Man. Civilization. Society] - Moscow: Politizdat [in Russian].

Soros, G. (2008). The New Paradigm for Financial Markets: The Credit Crisis of 2008 and What It Means. PublicAffairs. Hardcover.

Soros, G. (2012). Pravda o finansovom krizise [The truth about the financial crisis] Retrieved from http://www.1pixel.ru/soroskriz.php [in Russian]

Vaslavskaya, I.Y., Yangirova, Y.Y. (2015). Russian new industrialisation policy as a change-over method to the postindustrial economics. Mediterranean Journal of Social Sciences, 6(3), 174-180. DOI: 10.5901/mjss.2015.v6n3p174

\section{Notes}

Note 1: Russian Humanitarian Science Foundation.

Note 2: Mineral Extraction Tax. 